DOI: $10.36695 / 2219-5521.4 .2019 .19$

УДК 342.95 (043.3)КПІ (091)

\title{
I.B. КОСТЕНКО
}

Ірина Валентинівна Костенко, кандидат юридичних наук, доцент, доцент Національного технічного університету України «Київський політехнічний університет імені Ігоря Сікорського»*

ORCID: 0000-0001-6700-4194

\section{ОСНОВНІ ПРИНЦИПИ ЕЛЕКТРОННОГО УРЯДУВАННЯ}

Постановка проблеми. В умовах формування інформаційного суспільства, на початку XXI ст., у світі виникло поняття «електронне урядування», E-government. Молода незалежна Українська держава, яка отримала у спадок архаїчний механізм управління, не залишилась осторонь цієї глобальної світової тенденції. На початку 2000 рр. в Україні була прийнята ціла низька законів та підзаконних актів 3 цього питання. Станом на сьогодні у нашій країні розроблена розвинена нормативна база для впровадження будь-якої з існуючих у світі моделей електронного урядування. Україна, в аспекті імплементації електронного урядування, $\epsilon$ молодою державою. У світовій же практиці вже є певний напрацьований досвід, склалось декілька основних моделей електронного урядування: англо-американська, європейська, азійська моделі.

Органи державної влади США, наприклад, при створенні системи електронної взаємодії з громадянами, зробили основний акцент на створенні необхідної інформаційної інфраструктури. Такий підхід дає змогу перейти від бюрократичної моделі управління до «сервісної влади» - моделі управління, яка спрямована на забезпечення громадян необхідною інформацією та надання їм послуг. Аналогічна тенденція досліджується зараз і в Україні.

Аналіз останніх досліджень і публікацій. Досвід впровадження е-демократії та е-урядування в Україні досліджували С.В. Дзюба та В.Ф. Нестерович. Питання створення ефективного урядування вивчав О. Дергачов. Питання електронної демократії, за досвідом США, аналізував І.П. Лопушинський. М.С. Демкова, І.Б. Жиляєв, Н.Н. Клищ, К.О. Линьов, С.В. Політанський, М.В. Фігель висвітлювали різні аспекти електронного урядування в Україні і світі. Для цієї статті корисним став підручник «Технології електронного урядування» І.В. Клименко. Також нами була опрацьована значна база нормативно-правових джерел із досліджуваного питання.

Таким чином, вибір теми зумовили соціальна і наукова актуальність досліджуваного питання, недостатній рівень його теоретико-методологічної розробленості.

Формулювання мети статті. Метою дослідження є зміст та принципи електронного урядування та стан його впровадження у сфері публічного управління України.

Виклад основного матеріалу. Перш ніж переходити до дослідження основних принципів електронного урядування слід, визначитися з понятійно-категоріальним апаратом, який буде використовуватись у даній статті.

Світове співтовариство в обличчі Організації Об'єднаних Націй (далі - ООН) визначає електронний уряд як уряд, який, використовуючи інформаційно-комунікаційні технології, надає громадянам та підприємствам можливість взаємодіяти 3 урядом, використовуючи різноманітні електронні засоби масової інформації1.

ООН визначає електронне урядування в двох підходах: як системне використання ІКТ урядом для взаємодії з громадянами і підприємствами та для спрощення й удосконалення демократичного управління.

Концепція Кабінету Міністрів є найбільш сучасним нормативним актом, який створює умови впровадження е-урядування в Україні. Концепція використовує наступне визначення: електронне урядування форма організації державного управління, яка сприяє підвищенню ефективності, відкритості та прозорості діяльності органів державної влади та органів місцевого самоврядування з використанням інформаційнотелекомунікаційних технологій для формування нового типу держави, орієнтованої на задоволення потреб громадян ${ }^{2}$.

Іншим був підхід авторів «Концепції електронного урядування в Україні», створеної за підтримки Міжнародного фонду «Відродження». За їх баченням, електронне урядування - це форма організації державного управління, за якої відбувається активна взаємодія органів державної влади та органів місцевого самоврядування з суспільством, людиною, бізнесом, за допомогою інформаційно-комунікативних технологій ${ }^{3}$.

На думку В.М. Фурашева, електронний уряд - це система державного управління, яка 3 метою підвищення ефективності своєї діяльності зорієнтована на максимальне реальне впровадження та використання новітніх досягнень науки і техніки, зокрема у сфері інформаційно-комунікаційних технологій 4 .

(C) І.В. Костенко, 2019

* Irina Kostenko, Ph.D. in Law, Associated Professor, Associate Professor of the National Technical University of Ukraine "Igor Sikorsky Kyiv Polytechnic Institute" 
Науковець підкреслює, що основною ланкою взаємодії між громадянами та органами державної влади чи місцевого самоврядування є людина (чиновник). Застосування сучасних інформаційно-комунікативних технологій дасть змогу мінімізувати участь людини у процесі надання громадянам адміністративних послуг, а відтак і надасть процесу необхідного рівня прозорості. Вартим уваги є те, що автор вважає єдино можливим реалізацію державної політики з питань електронного урядування через впровадження системи «Електронний уряд» - єдиної інфраструктури міжвідомчої автоматизованої взаємодії у інтерактивному режимі наближеному до реального масштабу часу, органів державної влади та органів місцевого самоврядування між собою, з громадянами і суб'єктами самоврядування5.

Виникає питання, чому ж існує така різниця в судженнях світових експертів та українських урядовців і науковців?

Основним аспектом, що вплинув на різницю у поглядах, є історичний. Радянська спадщина напряму вплинула на формування моделі електронного урядування в Україні, його принципи, завдання та цілі. Під поняттям радянська спадщина мається на увазі та модель управління, яка «перейшла у спадок» Україні. Бюрократизм, помножений на заплутані процедури, і став першопричиною корупції в тих масштабах, які ми маємо сьогодні. Здається, що при побудові радянської системи управління мали на меті інтереси чиновників, а не громадян.

Політичні зміни 2014 р. повністю змінили вектор як внутрішньої, так і зовнішньої політики України. Закони «Про очищення влади» та «Про засади запобігання та протидії корупції» поставили за мету підвищення ефективності влади, прозорості, збільшення контролю з боку громадськості.

Відштовхуючись від принципових положень законодавства про боротьбу з корупцією, Концепція Кабінету Міністрів увібрала в себе всі принципи антикорупційних законів, чітко окресливши мету електронного урядування та коло проблем, які вона повинна вирішити.

За результатами розгляду чотирьох наведених точок зору на поняття «електронне урядування» позиція Кабінету Міністрів у Концепції видається найбільш точною: електронне урядування - форма організації державного управління, яка сприяє підвищенню ефективності, відкритості та прозорості діяльності органів державної влади та органів місцевого самоврядування з використанням інформаційно-телекомунікаційних технологій для формування нового типу держави, орієнтованої на задоволення потреб громадян 6 .

Електронне урядування можна вважати одним із способів врегулювання суспільних відносин. Існування і функціонування цього інституту має підпорядковуватись певним принципам. У загальному розумінні принципи, за своєю сутністю, є основоположними ідеями, які визначають зміст і спосіб правового регулювання.

ООН, як наддержавне формування, виділяє наступні принципи функціонування інституту «електронного урядування»:

- використання інформаційно-комунікативних технологій у процесі функціонування;

- заохочення участі громадян у процесі прийняття управлінських рішень;

- підвищення підзвітності діяльності органів державної влади;

- прозорість управлінського процесу;

- ефективність урядування.

Варто проаналізувати кожен з цих принципів. Першим принципом є широке використання інформаційно-комунікативних технологій. Цей принцип є, скоріше, не принциповим положенням, на якому буде вибудовуватись і реалізовуватись стратегія, а, скоріше, простою констатацією, що управління державними справами буде переходити на електронну безпаперову (цифрову) форму. Відповідно до принципів ООН, до інформаційно-комунікативних технологій відносять: факсимільний зв'язок, електронний облік та електронні реєстри, пункти самообслуговування, Інтернет, електронну пошту та електронний обмін даними. Звичайно, сьогодні такий перелік не є інноваційним.

Заохочення громадян в управлінні державними та муніципальними справами - основоположний принцип державного управління сучасної держави. Через систему електронних звернень громадянам надана можливість, зібравши необхідну кількість підписів, надати управлінцям інформацію про існуючі проблеми, а також можливість висловити свою думку стосовно питань регіонального та державного значення, а проста ідентифікація через BankID дає можливість залучити широке коло громадян.

Принцип підвищення підзвітності діяльності органів державної влади постає як ключовий контролюючий принцип електронного урядування. Варто зазначити, що підзвітність та прозорість діяльності тісно пов’язані між собою. Слід сказати, що безпаперова форма діяльності управлінців, з одного боку, економить час прийняття управлінських рішень, але, з іншого боку, призводить до безвідповідальності. Задля реалізації принципу прозорості та підзвітності управлінець, на нашу думку, кожне своє рішення має підтверджувати електронним цифровим підписом. У держави мають існувати відкриті реєстри абсолютно всіх управлінських рішень, що приймаються, незалежно від рівня органу, який їх приймає, крім тих, звичайно, що містять державну таємницю.

Отже, принцип відкритості та прозорості реалізується через три складові: право «знати», «отримувати», та «впливати». Право «знати» - це можливість громадян мати необхідну інформацію про управлінські та інші державні рішення, без особливих часових затрат. Право «отримувати» - це можливість громадян, громадських інституцій та бізнесу отримати необхідні публічні послуги в найкоротші строки. Право «впливати» - це можливість громадян впливати на управлінські рішення, брати участь у їх прийнятті через громадські слухання, а також донести свою точку зору через систему електронних звернень. 
Ефективність урядування виступає, скоріше, не як принцип електронного урядування, а, більше, як його кінцева мета. Так, широке використання інформаційно-комунікативних технологій покликане оптимізувати ресурсні витрати в фінансовому аспекті (скоротити штат працівників), мінімізувати часові витрати.

Отже, у баченні ООН електронне урядування постає як оптимізована необхідними інформаційно-комунікативними засобами ефективна модель управління, побудована на принципах прозорості, підзвітності та участі громадян в управлінні.

Концепція розвитку електронного урядування, затверджена Кабінетом Міністрів, має дещо інший, більш сучасний підхід, до визначення принципів запровадження eGovernment в Україні. Так, за Концепцією, електронне урядування в Україні будується на наступних принципах:

- цифровий за замовчуванням - забезпечення будь-якої діяльності органів влади (у тому числі надання публічних послуг, забезпечення міжвідомчої взаємодії, взаємодії з фізичними та юридичними особами, інформаційно-аналітична діяльність) передбачає електронну форму реалізації як пріоритетну;

- одноразове введення інформації - реалізація підходу, за якого фізичні та юридичні особи лише один раз подають інформацію до органів влади, а в подальшому ця інформація повторно використовується органами влади для надання публічних послуг та виконання інших владних повноважень 3 дотриманням вимог захисту інформації та персональних даних. Створений у січні 2013 р. Єдиний портал адміністративних послуг дає можливість отримати адміністративну послугу через кабінет користувача на електрону пошту, шляхом проходження ідентифікації через електронний цифровий підпис. Всі персональні дані внесені до кабінету зберігаються та захищаються, що дає можливість неодноразово користуватись персональним кабінетом для отримання адміністративних послуг в подальшому;

- сумісність за замовчуванням - здійснення проектування та функціонування інформаційно-телекомунікаційних систем в органах влади відповідно до єдиних відкритих вимог і стандартів для забезпечення їх подальшої сумісності та електронної взаємодії та повторного використання.

Одним із двох принципів, які відсутні в офіційній Концепції, є принцип партнерства. Принцип представницької демократії передбачає, що управлінець - це не більш ніж сервісний персонал, найнятий громадянами України для виконання покладених на нього обов'язків, який отримує за це заробітну платню з бюджету держави, сформованого з податків, сплачених громадянами. Тому, на нашу думку, недостатньо принципу «залучення громадян» у тексті Концепції. Уряд має чітко усвідомлювати, що народ треба сприймати як рівного партнера у взаємовідносинах.

Крім того, варто зазначити, що система принципів побудови системи електронного урядування має бути доповнена принципом відповідальності посадової особи, яка приймає рішення, за вирішення цієї проблеми.

В українському законодавстві існує архаїчне поняття адміністративної відповідальності, як виду відповідальності за порушення існуючого громадського порядку - передусім відповідальність громадян. Однак закордонна практика також схиляється до визначення адміністративної відповідальності як відповідальності державних службовців за невиконання чи неналежне виконання покладених на них обов'язків. На нашу думку, виконавча влада в Україні має нести відповідальність перед громадянами за свої рішення, дії чи бездіяльність, в тому числі і в сфері розвитку електронного урядування. Діяльність Антикорупційного суду та реформи в сфері адміністративної відповідальності - ось необхідний мінімум, який забезпечить підвищення прозорості та ефективності публічного управління.

Певні крокі у галузі електронного урядування в Україні вже зроблено. На Урядовому порталі наразі доступні 118 електронних послуг, користування якими минулого року зросло втричі,

Радник Президента Михайло Федоров у грудні 2019 р. під час презентації моделі «держава у смартфоні» зазначив: «Ключова мета зараз - визначити конкретні шляхи та механізми прискорення реалізації цього амбітного проекту, зробити електронний уряд більш технологічним, зручним і суттєво збільшити кількість його користувачів. Нам потрібно реалізувати ідею “єдиного вікна”, дати громадянам одну веб-адресу всіх наявних послуг, впровадити єдину систему авторизації та ідентифікації, зробити загалом усю систему більш орієнтованою на потреби громадян, впровадити уніфіковані принципи щодо дизайну та інтегрувати наявні електронні послуги в єдиний технологічний “фреймворк”, що дасть змогу ще активніше залучати громадян до цифрового світу» 7.

Висновки. Отже, сьогодні в наукових колах Україні не існує одностайної думки стосовно визначення поняття «електронне урядування». 3 одного боку, електронне урядування розглядається як новий метод управління. 3 іншого боку - як система міжвідомчої взаємодії, як концепція підвищення ефективності та прозорості діяльності органів державної влади, яка повинна насамперед мінімізувати владу чиновника. У процесі написання статті було сформульовано наступне визначення: електронне урядування - форма організації державного управління, яка сприяє підвищенню ефективності та прозорості діяльності органів державної влади та органів місцевого самоврядування з використанням інформаційно-телекомунікаційних технологій для забезпечення подальшого розвитку демократичного суспільства.

Також у ході аналізу принципів електронного урядування, відповідно до урядової Концепції, було сформульовано ще два додаткових принципи: принцип партнерства та принцип відповідальності посадової особи. Принцип партнерства полягає у сприйнятті громадян та їх об'єднань як рівноправних партнерів у процесі прийняття управлінських рішень. У законі повинна бути визначена міра відповідальності посадовця за невиконання прийнятих рішень. 
1 United Nation E-Government Survey. URL: https://publicadministration.un.org/egovkb/Portals/egovkb/Documents/un/2018Survey/E-Government\%20Survey\%202018_FINAL\%20for\%20web.pdf

2 Про схвалення Концепції розвитку електронного урядування в Україні: розпорядження Кабінету Міністрів України від 20 вересня 2017 р. № 649-p. Офіційний вісник Украӥни. 2017. № 78. Ст. 109. URL: https://zakon.rada.gov.ua/laws/show/649-2017$\% \mathrm{D} 1 \% 80$

${ }^{3}$ Концепція розвитку електронного урядування в Україні / О. Баранов, А. Семенченко. URL: https://www.irf.ua/files/ukr/ conception final.pdf

${ }^{4}$ Складові електронного урядування / Правова інформатика. - 2012. URL: http://ippi.org.ua/sites/default/files/12fvmseu.pdf

${ }^{5}$ Концепція розвитку електронного урядування в Україні / О. Баранов, А. Семенченко. URL: https://www.irf.ua/files/ukr/ conception_final.pdf

6 Про електронні документи та електронний документообіг: Закон України. URL: http://zakon.rada.gov.ua/laws/show/851-15/

7 Держава у смартфоні. URL: https://www.ukrinform.ua/rubric-technology/2709578-derzava-u-smartfoni-na-bankovij-anonsu vali-prezentaciu-dla-ekspertiv-i-gromadan.html

\section{References:}

United Nation E-Government Survey (2018). URL: https://publicadministration.un.org/egovkb/Portals/egovkb/Documents/un/ 2018-Survey/E-Government\%20Survey\%202018_FINAL\%20for\%20web.pdf [in English].

Rozporiadzhennia Kabinetu Ministriv Ukrainy vid 20 veresnia 2017 r. № 649-r "Pro skhvalennia Kontseptsii rozvytku elektronnoho uriaduvannia v Ukraini”. Ofitsijnyj visnyk Ukrainy. (2010). 97, 3443. URL: https://www.kmu.gov.ua/ua/npas/250287124 [in Ukrainian].

Baranov, O., Semenchenko, A. (2009). Kontseptsiia rozvytku elektronnoho uriaduvannia v Ukraini. URL: https://www.irf.ua/ files/ukr/conception_final.pdf [in Ukrainian].

Skladovi elektronnoho uriaduvannia. Pravova informatyka. (2012). URL: http://ippi.org.ua/sites/default/files/12fvmseu.pdf [in Ukrainian].

Zakon Ukrainy "Pro osnovni zasady rozvytku informatsijnoho suspil'stva v Ukraini na 2007-2015 roky". URL: http://zakon. rada.gov.ua/laws/show/537-16/ [in Ukrainian].

Zakon Ukrainy "Pro elektronni dokumenty ta elektronnyj dokumentoobih. URL: http://zakon.rada.gov.ua/laws/show/851-15/ [in Ukrainian].

"Derzhava u smartfoni». URL: https://www.ukrinform.ua/rubric-technology/2709578-derzava-u-smartfoni-na-bankovij-anonsu vali-prezentaciu-dla-ekspertiv-i-gromadan.html [in Ukrainian].

\section{Резюме}

Костенко І.В. Принципи електронного урядування.

У ході аналізу принципів електронного урядування було сформульовано ще два додаткових принципи: принцип партнерства та принцип відповідальності посадової особи. Принцип партнерства полягає у сприйнятті громадян та їх об'єднань як рівноправних партнерів у процесі прийняття управлінських рішень. У законі повинна бути визначена міра відповідальності посадовця за невиконання прийнятих на себе зобов'язань.

Ключові слова: електронне урядування, принципи електронного урядування.

\section{Резюме}

Костенко И.В. Принципы электронного управления.

В работе предложено дополнить общепризнанные принципы электронного управления принципом партнерства и принципом ответственности должностного лица за принятое решение. Принцип партнерства заключается в восприятии граждан и их объединений как равноправных партнеров в процессе принятия управленческих решений. Также нужно закрепить в законе норму, согласно которой за незаконные действия или бездействие должностное лицо должно привлекаться к ответственности.

Ключевые слова: электронное управление, принципы электронного управления.

\section{Summary}

\section{Irina Kostenko. Principles of e-Governance.}

Formulation of the problem. In the early 21 st century, the concept of e-government, E-government, emerged in the world. The young independent Ukrainian state, which inherited the archaic governance mechanism, has not stayed away from this global trend.

As of today, Ukraine has developed progressive regulatory framework for implementing any of the existing e-government models in the world. Ukraine, in terms of implementation of e-governance, is a young country. There is already some experience in the world practice, there are several basic models of e-government: Anglo-American, European, Asian models.

Thus, the choice of topic was determined by the social and scientific relevance of the studied issue, the lack of its theoretical and methodological development.

Formulating the purpose of the article. The purpose of the study is the content and principles of e-governance and the state of its implementation in the sphere of public administration of Ukraine.

At the time of writing, the author came to the following conclusions. Today, there is no unanimous opinion in the scientific community regarding the definition of "e-governance".

On the one hand, e-government is seen as a system of interagency interaction, as a concept of increasing the efficiency and transparency of the activity of public authorities, which should minimize the involvement of the official person. In the process of writing the work, the following definition was formed: e-government is a form of public administration that promotes the efficiency and transparency of the activity of state and local self-government bodies using information and telecommunication technologies to ensure the further development of a democratic society. Also, two additional principles were formulated in the analysis of e-Government principles in accordance with the Government Concept: the partnership principle and the responsibility of the official person. The principle of 
partnership is to perceive citizens and their associations as equal partners in the decision-making process. The law should specify the degree of responsibility of the official person for non-compliance with the adopted decisions.

Key words: e-governance, principles of e-governance.

DOI: $10.36695 / 2219-5521.4 .2019 .20$

УДК 342.9

\title{
В.А. МИКОЛАєЦЬ
}

\author{
Вікторія Анатоліївна Миколаєць, кандидат \\ юридичних наук, докторант МАУП*
}

ORCID: 0000-0002-9731-3884

\section{ЗРАЗКОВІ ТА ТИПОВІ СПРАВИ В АДМІНІСТРАТИВНОМУ СУДОЧИНСТВІ ЛИТВИ}

Постановка проблеми. Згідно зі ст. 55 Конституції України ${ }^{1}$ кожному гарантується право на оскарження в суді рішень, дій чи бездіяльності органів державної влади, органів місцевого самоврядування, посадових і службових осіб. Тобто гарантування захисту прав громадян у відносинах з адміністративними органами є обов’язком держави, який став однією із першопричин створення в Україні адміністративної юстиції, яка, з одного боку, захищає права громадян, а, з іншого, забезпечує законність діяльності органів державної влади. Із самого початку створення адміністративної юстиції в наший державі вітчизняний законодавець опирався на досвід іноземних держав, передусім європейських. Йдеться не про механічне перенесення окремих елементів зарубіжних моделей, а про реформування національного законодавства згідно 3 чинними соціально-політичними умовами, досвідом більш розвинених держав, а також із урахуванням національних правових традицій. Тож теоретичні та прикладні розробки щодо запровадження в Україні адміністративної юстиції європейського зразку не втрачають своєї актуальності, а тому дослідження будь-яких правових інститутів доречно здійснювати крізь призму досвіду тих держав, які успішно їх впровадили в свої правові системи.

В основу механізму зразкових та типових справ в адміністративному судочинстві ліг інститут пілотних рішень, які виносить Європейський суд з прав людини. 3 часу прийняття першого пілотного рішення застосування даного інструменту було спрямовано насамперед на зменшення навантаження на суди та суддів. За своєю сутністю пілотні рішення Свропейського суду з прав людини являють собою вказівки державним органам на існування системної проблеми, яка стосується великої кількості осіб, та рекомендації щодо усунення виявлених порушень. Шляхом впровадження інституту пілотних рішень було розв'язано одразу два завдання: по-перше, впроваджено інститут, спрямований на вирішення багаторазово повторюваних проблем; по-друге, даний механізм сприяв вирішенню справ, що випливають зі стійкого системного неправильного функціонування адміністративних і правозастосовних органів правової системи держави. Як зазначається в науковій літературі, така процедура була впроваджена у багатьох судових системах Свропи: в Угорщині, Португалії, Франції, Італії, Австрії, Словенії, Литві. Водночас існує практика, коли європейські країни відмовились від впровадження таких процедур. Наприклад, законодавці Латвії аргументували свою незгоду 3 даним нововведенням можливими запереченнями учасників процесу проти визначення справи як типової для постанови зразкового рішення; тим, що фактичні обставини у справі можуть різною мірою відрізнятися, а суд може їх врахувати як ідентичні; а також тим, що у зв'язку із запровадженням цього інституту зросте навантаження на Верховний Суд². Україна у даному контексті стала на сторону держав, у яких функціонують механізми зразкових та типових справ в адміністративному судочинстві, і при цьому відсутня певна єдина модель, досвід якої було запозичено Україною. Український варіант зразкових та типових справ в адміністративному судочинстві не був повністю скопійований із певної конкретної моделі й має свої особливості.

Аналіз останніх досліджень та публікацій. Серед дослідників зарубіжних моделей механізму зразкових та типових справ в адміністративному судочинстві відзначимо внесок таких, як: С.В. Боднар, М.А. Бояринцева, А.В. Журавльов, В.В. Ільков, І.А. Качур, І.В. Мирончук, Л.І. Пахолок, В.Б. Пчелін, А.О. Селіванов, Т.Г. Стрілець, А.О. Черникова, В.І. Шишкін. Але водночас варто враховувати те, що праці перелічених авторів були присвячені більш загальним питанням адміністративного судочинства, які у тому числі стосувалися й інститутів зразкових та типових справ. Також із даного приводу варто зазначити, що впровадження даних механізмів у Кодексі адміністративного судочинства України ${ }^{3}$ не применшило актуальності наукових досліджень зарубіжних моделей, а навпаки, надало таким дослідженням важливого значення. Зарубіжний досвід функціонування механізмів зразкових та типових справ в адміністративному судочинстві має вивчатись $\mathrm{i}$ надалі з метою вдосконалення чинного законодавства, практики його застосування, продовження процесу приведення існуючої правової системи до міжнародних стандартів.

(C) В.А. Миколаєць, 2019

* Victoria Mykolayets, Ph.D. in Law, Doctoral candidate of the Interregional Academy of Personnel Management 